\title{
TOURISM INDUSTRY REGIONAL ASPECTS
}

REGIONÁLNÍ ASPEKTY CESTOVNÍHO RUCHU

\section{PROF. PHDr. KAREl LACINA, DRSc.}

Vysoká škola finanční a správní, o.p.s. | University of Finance and Administration $\bowtie$ Estonská 500, 10000 Praha, Czech Republic

E-mail:kar.lacina@seznam.cz

\begin{abstract}
Annotation
Tourism industry is dynamically developed not only in the European continent but also in the North America, Asia, the Middle East, Australia and in the Pacific area predominantly in the last twenty five years. It represents the source of precious effects as the tourism activities implementation in regions closely connected with the improvement of different tourism industry services has an important share in the growth of municipalities and regions economic and social potential. Its role is especially apparent in villages regions where mainly the development of agrotourism, ecotourism and eco-agrotourism together with biketourism significantly contribute to their economic and social stabilization.
\end{abstract}

\section{Key Words}

tourism industry, regions, regional development strategies, village tourism industry, regional tourism industry strength and weakness, biketourism

\begin{abstract}
Anotace
Cestovni ruch se nejen na evropském kontinentu, nýbrž $i$ v Severni Americe a rovněž v Asii, na Blizkém a Středním východè, Austrálii a v Oceánii dynamicky rozviji zvláště v posledním čtvrtstoletí. Je zdrojem cenných efektů, nebot' uskutečňováni turistických aktivit v regionech úzce spojené se zkvalitňováním nejri̊znějšich služeb cestovniho ruchu se významným způsobem podilí na růstu ekonomického a sociálního potenciálu municipalit a celých regionů. Jeho př́nos je zvláště patrný ve venkovských regionech, v nichž zejména rozvoj agroturistiky, ekoturistiky a eko-agroturistiky spolu $s$ aktivizaci cykloturistiky $v$ nemalé miŕre přispivaji k jejich hospodářské $i$ sociálni stabilizaci.
\end{abstract}

\section{Klíčová slova}

cestovni ruch, regiony, regionální rozvojové strategie, venkovský cestovni ruch, silné a slabé stránky regionálního cestovního ruchu, cykloturistika

JEL classification: $R O O$

\section{Introduction}

The role of regions in the economic and political affairs including the tourism industry is increasing in Europe, Northern American and other countries mainly during the last fifty years. The indicated trend is connected in the European continent - among others - with the public administration reforms, first of all with the decentralization, deconcentration and subsidiarity principles implementation. One of its results became the creation of regional state administration and local government that did not exist de facto before the beginning of reform activities. This trend was partly reflected in the sphere of tourism activities. The tourism industry contributes now effectively to the development of the whole regions predominantly thanks to the generation of incomes from products and services purchase to tourists and to the creation of new labour places.

The regional dimension of tourism activities is underlined by the fact that they are developing mainly in concrete regions, microregions and in the territory of municipalities. Those territories, of course, 
differ in the framework of the state territory what concerns their attractiveness. In general there are regions attractive for tourism and other which are visited by tourists only in a relatively limited moments. Pardubice region in Eastern Bohemia could be mentioned as the example of the second group of regions. Nevertheless tourism activities represent in such a way important challenges for regions with prevailing agrarian economy from the point of view of their economic and social development. Different forms of tourism are developing in agrarian regions based mainly on villages tourism activities. The experience of countries with rich traditions of tourism industry confirm the fact that tourism activities are successfully developed predominantly in territories where elected representatives closely cooperate with the Small and Medium-sized Enterprises owners and managers. Taking this fact into account strategies worked out for tourism can be formulated nowadays very often as the component parts of their widely outlined strategies in the majority of regions.

The principal tourism activities in regions are concentrated predominantly to:

1. Investments into construction of hotels, the purchase of modern transport means and in the construction of highways and other communications.

2. The strengthening of cooperation among the entrepreneurs, local government and the public administration authorities and offices based on the principle of partnership and networking. The mentioned orientation is positively reflected - among others - in the creation of more worked out tourism industry strategies in the tourism destinations.

3. The new labour places creation in the tourism industry facilities.

4. The improvement of cultural monuments protection situated in regions and simultaneously the general educational level of the local inhabitants increasing.

The effectiveness of indicated strategies and their contribution to the regional development was confirm first of all in Spain, Portugal, Greece, Cyprus and in the Ireland.

Investments into tourism industry represent the significant contribution to the economic and social development especially in the villages regions. That is why the European Union and its individual member states have been supporting different project contributing, among others, to the diminishing of disparities among more and less developer regions. The mentioned orientation:

- allows to accumulate money in regions that have in general a lower economic potential;

- it represents one of the way leading not only to the economic but also to the social stabilization of those areas.

The EU strategy utilizing financial means from the structural and national funds to investments is based on the real fact that the European village regions are in a relatively complicated stage of their development for the longer time. There are two urgent problems which have to be solved in those regions. The first one is connected with the restriction of agricultural production in localities where it represented relatively recently the main or extremely significant sphere of economic activities.

The second problem - linked immediately with the first one - is the fact that the number of people living in the villages is somewhere (from different reasons) dramatically reducing.

The weakness of the most underdeveloped villages regions is represented generally by:

- their insufficient infrastructure;

- the low level of capital;

- the worse access of entrepreneurs to credits from banks and other financial facilities;

- the relatively long geographical distance of classical rural areas from main regional economic centers;

- the relatively high costs of transport connected with the purchase and sale of products.

Speaking more concretely this indicated unpleasant situation of villages regions was caused predominantly by the following facts:

- there are often limited transportation possibilities complicating the everyday transport of people from small villages to larger centers offering the local population possibilities to work. 
The mentioned situation is criticized for a long time especially by the young people moving more and more often from villages to towns;

- lower quality of roads maintenance is also complicating the general situation;

- there is a limited number of créches, nursery and the elementary and secondary schools;

- the medical care quality is often limited there in the comparison with towns;

- only limited number of services is offered to citizens in smaller municipalities;

- the village areas are able to create only limited number of labour places for their inhabitants.

These and other problems are motivating inhabitants of villages to their migration to towns with much higher quality conditions for the everyday lie.

The fact that limited number of inhabitants lives predominantly in the mountain areas is negatively reflected also in the worse quality of soil cultivation. Therefore part of fields that don't have the highest value is transferred into forests or it is grassed down. In such a way pleasant preconditions for the development of agrotourism, ecotourism and eco-agrotourism are created here.

The attractiveness of the indicated characteristic features of the village tourism are caused by:

- its more sensitive relationship to the nature;

- limited (therefore more intimate) accommodation capacities;

- offer of pleasant environment in farms and small boarding houses;

- more better approach of services producers to visitors individual needs satisfaction;

- additional services provision (like for example horse riding, hunting, fishing);

- the possibility of local traditions, handicrafts, ways of soil cultivation recognition.

In other words tourism activities in villages areas:

- provide the possibility of recreation in the healthy and nontraditional environment;

- assure additional incomes for farmers and the assistance to villages stabilization in such a way;

- enable the folk architecture conservation together with folk traditions preservation;

- stimulate global villages development and protect the traditions of villages style of life.

The modern forms of tourism activities - agrotourism, ecotourism and eco-agrotourism - offer new work places for the local population. They represent the realistic contribution to the regions development because more and more tourists visiting village areas estimate predominantly:

- the local healthy environment;

- the natural and historical monuments situated here.

Their number is increasing relatively quickly. The agrotourism, ecotourism and eco-agrotourism represent the successful economic and social orientation mainly in municipalities where the principle Public-Private-Partnership is developed. The entrepreneurs are building here new accommodation and catering capacities and the local government is helping to them by the construction of technical infrastructure and information centers as well as by the activation of the cross border cooperation implemented in the territory of the so called euroregions. That is why agrotourism, ecotourism and eco-agrotourism are supported partly from the European Agriculture Guarantee and Guidance Fund and from the European Regional Development. Other resources for those regions development are represented by several specialized programs, first of all the so called Framework Programs.

The most famous of the Framework Programs are:

- European Research Project called „Making Agriculture Sustainable“ (MAS);

- "Capitalization of Research Results on the Multifunctionality of Agriculture and Rural Areas";

- „The Socio-Economic Impact of Rural Development Policies“.

Financing from them is oriented mainly to case study mapping predominantly the economic and social development of rural areas working out. 


\section{Main forms of villages tourism}

As it has been mentioned the most famous form of the villages tourism are agrotourism, ecotourism and eco-agrotourism. All of them represent the recreation possibilities in the villages environment (usually in the families farms). Visitors sojour here is often connected with further activities, first of all with biketourism.

The most famous of those forms is agrotourism successfully developed mainly in the tourism attractive regions in the mountains and in localities near mountains. Nevertheless the example of Netherlands document the success of agrotourism also in the lowlands.

The agrotourism is sometimes internally divided into so called:

- free agrotourism and

- accommodation facility-based tourism.

The so called free agrotourism (characterized sometimes also as active or individual agrotourism) is represented de facto by several days wandering from one farm to another one.

The accommodation facility-based tourism is implemented in the following types of the accommodation:

- traditional family farm;

- village hotel or boarding house

fulfilling criteria of environment protection (often near the Protected Preserved Areas - for example National Parks).

Ecotourism - with the annual increase about 15 per cent to 30 per cent - is one of forms of the so called soft tourism. In comparison with agrotourism it is more oriented to the observation of the nature. That is why the most available conditions for its development are in parts of the nature enabling one or more days wanders.

In the Czech Republic ecotourism often connected with biketourism is exercised by the Czech and foreign tourists - mainly from the Netherlands.

The eco-agrotourism is developed predominantly without the use of fertilizers in their plants growing. The cows, sheep, goats and horses are reared in the traditional natural way here. The mentioned style of agricultural production is considered to be very attractive by the eco-agrotourism participants.

If we try to proceed to the generalization of the indicated activities it is possible to underline predominantly the following facts:

- The village forms of tourism enable to utilize and to appraise the uniqueness of the villages as well as the relatively clear environment.

- Village tourism contributes significantly to new work places creation.

- It enable to prepare and to offer refreshment for visitors from local agricultural products.

\section{Role of cycle touring in rgional tourism industry development}

There are several important advantages of cycle touring preference not only in the villages but also in the towns. Following aspects are considered generally as the most valuable:

- the cyclists need not find parking places in the towns which there is only limited number of them due to the cars transportation density;

- cyclists do not participate in traffic jams.

- cyclists do not make a noise;

- cyclists do not contaminate the environment;

- the development of cycle touring has pleasant medical effects. 
Taking the presented advantage into account cycle touring was developed as the efficient king of tourism industry predominantly due to the financial and other material support from the governments in several European countries. The European Union is one of -the „EuroVelo“ project co-financiers. It principle aim is to connect all EU countries by cycle routs till year2016. The United Kingdom, first of all Scotland, could be a good example of the effective participation in such an approach. The Scottish ministers council announced the program called „Scottish Initiative in Biking Development" already in year 1996. This program has been implemented and financed since the financing year 1998-1999. Its main intention was the „National Biking Strategy“ implementation.

Eighty applicants for the financial support have been chosen from the public and private sectors as well as among members of voluntary working groups and local tourism organizations. Each of their eighty projects was assessed on the basis of a relatively strict criteria. 37 best projects have been definitely adopted with global subsidy of approximately 650000 pounds (cca 1,1 mil. Euro). Further biking projects were subsidized during the first decade of the 21 st century.

In the continental Europe Switzerland is another European country where cycle touring is permanently supported from the state administration and the local government resources. Its first supporters were towns and regions. Nowadays the vast majority of the cycle touring routs is contructed in the regions (cantons). That is why the cycle touring represents here an important role in the regional tourism industry.

The contemporary primary task in the level of the whole Switzerland is to connect cantons by bike routes. It is the essence of the project called ,Veloland Schweiz" based on the putting into service cycle touring routs in the global length of 3330 kilometers (including the construction of complete infrastructure).

The „EuroVelo“ project influence is visible also in the Federal Republic of Germany. Several long cycle touring routes were constructed - but not mutually connected - here in the 1980s and in the beginning of the 1990s. Therefore the ADFC (the tourism organization with high reputation) started to cooperate with the German Tourism Headquarters (DFV). The main result of the mentioned cooperation represented the project „Find Germany in Bicycle“. Nowadays the network of cycle touring routes with the total length of 37000 kilometers represents the project „EuroVelo “ component part. The project offers the ,packet" of different but connected services from the suitable accommodation and the network of bicycle repair shops to information provision concerning different activities for biketourists organization.

The so called „pressure policy“,, in favour of cycle touring achieved the victory in the Netherlands. One of its principal priorities are the construction of perfect and cheap parking places for cycle tourists in towns where parking places for cars are extremely expensive. The so called „Universal Cycle Plan " was adopted by the government. It underlines the role of bicycle as one of means serving to the quality of environment improvement - predominantly in towns. This project represented the answer to serious economic and environmental problems since the 1960s when the environment in the Netherland was extremely polluted. Thanks to the governmental activities bicycles are now the means of transport number two - after cars - in the Netherlands. Dutch people use them for about 30 per cent of their tours.

The further examples of bicycles utilization for citizens transport is possible to find also in other European countries, for example in Denmark, Austria and in France.

Speaking about the European size of cycle touring it is possible to come to the conclusion that the cycle touring propagation contributed in Western European countries to the prosperity of smaller territories with the suitable flat terrain - and very often also with a greater density of cultural monuments. 


\section{Cycle touring in the Czech Republic}

The cycle touring development in the Czech Republic is closely connected with the „Program of Countryside Restoration". Projects of long-distance cycle touring routes connected with the European bike routes EuroVelo were worked out and their implementation started. One of them is, for example, the important "Cycle Touring route Prague - Dresden“ project which could connect towns and villages from Central a Western Bohemia with the capital of Saxony in Germany. The famous so called „Moravian-Silesian Long-distance Cycle Rout" was constructed in Northern Moravia. The cycle routes project „Beautiful Country" that connecting eight Czech Republic regions was worked out and implemented. Nowadays it is possible to visit mentioned regions during 22 days of tours what could be interesting for cycle tourists from different European countries.

It is expected in the Czech Republic that one of the tourism industry principal goal will be the construction of sufficient number of motels, hotels and pensions for biketourists complemented by a network of specialized shops for them, maintenance services and other facilities supporting the cycle touring development.

\section{Conclusion: tourism activities in regions contribution}

Generalizing, tourism activities strategies in regions are oriented predominantly to:

1. The support of tourism industry infrastructure:

with the emphasis on cycle routes and water activities spaces, cars and buses parking areas, accommodation and gastronomy facilities, camps and information centers construction, the cultural, entertainment and sport infrastructure, technical information systems as well as ski routes quality improvement.

2. Regional tourism industry organization structure building and its quality improvement with the principal orientation to the regional and local tourism organizations network stabilization and regional information centers activities development.

3. Efforts aimed at the tourism destinations image increasing:

The orientation to the long-term marketing activities improvement oriented to the regions effective propagation seems to be the way of the mentioned goal implementation. The similar significance has the education and training of the tourism industry facilities staff.

4. The support of cultural and natural inheritance regeneration.

5. The regional tourism helps municipalities to utilize incomes for tourism for different local activities

- The regional tourism influence positively the payment balance municipalities and the whole regions.

Facts informing about tourism activities development in the traditional tourism destinations in the European and non-European countries confirm the fact that the key instruments of tourism industry stimulation in regions are:

- the growth of destination management quality with the accent to the improvement of the tourism activities coordination and support including the better utilization of information and monitoring systems;

- the accumulation of financial sources from national and EU supporting programs predominantly for the architecture monuments conservation and for the care of nature as the whole;

- several approaches typical for the strategic planning implementation.

\section{Literature}

[1] ČERNÁ J.,KAŠÍK M.,KUNZ V.: Public Relations (komunikace organizací). Praha: EUPress 2008. ISBN: 978-80-86754-65-9.

[2] INDROVÁ J. a kol. Cestovní ruch (základy). VŠE v Praze 2007. ISBN: 978-80-245-1252.

[3] INDROVÁ J., MALÁ V. Cestovní ruch. 1. vydání: VŠE v Praze 2004, ISBN: 80-245-0799-4. 
[4] JAKUBÍKOVÁ D. Marketing v cestovním ruchu. Praha: Grada Publishing,a.s. 2009. ISBN: 978-80-247-3247-3.

[5] KIRÁLOVÁ A. Marketing destinace cestovního ruchu. 1. vydání, Praha: Ekopress 2003, ISBN: 80-86119-56-4.

[6] Kolektiv autorů. Průmysl cestovního ruchu. Praha: Ministerstvo pro místní rozvoj 2008.

[7] LACINA K. Management a marketing cestovniho ruchu. Praha: EUPress 2010, ISBN: 978-807408-035-7.

[8] LACINA K. Regionální rozvoj a veřejná správa. Praha: EUPress 2007, ISBN: 978-80-8675474-1.

[9] MALÁ V. a kol. Základy cestovního ruchu. VŠE v Praze 2002, ISBN:80-245-0439-1.

[10] MORRISON A.M. Marketing pohostinství a cestovního ruchu. 1. vydání, Praha: Victoria Publishing 1995, ISBN: 80-85605-90-2.

[11] NĚMČANSKÝ M. Management cestovního ruchu. 1.vydání, Slezská univerzita v Opavě, Karviná 1995, ISBN: 80-85879-18-2.

[12] PALATKOVÁ M. Marketingová strategie destinace cestovního ruchu. Praha:Grada Publishing, 2006 ISBN: 80-247-1014 -5.

[13] PÁSKOVÁ M., ZELENKA J. Cestovni ruch - výkladový slovník. Praha: Ministerstvo pro místní rozvoj 2002.

[14] PETRŮ Z. Základy ekonomiky cestovního ruchu. Praha: IDEA SERVIS 2007. ISBN: 978-80-85970-55-5.

[15] RYGLOVÁ K. Cestovní ruch (soubor studijnich materiáli̊). Ostrava: KEY Publishing 2007, ISBN: 978-80-87071-44-1.

[16] VAŇÁK M., NAHODIL F. Základy marketingu. Praha: EUPress 2007. ISBN: 978-80-8675485-7.

[17] VAŠKO M. Cestovní ruch a regionální rozvoj. 1. vydání, VŠE v Praze 2002. ISBN: 80-2450445-6. 